\title{
Effect of Salinity Difference on Lipid Content from Chaetoceros muelleri on Continuous Reactors
}

\author{
Arif Rahmadi ${ }^{1 *}$, Yeni Mulyani ${ }^{2,3}$, Muhammad Wahyudin Lewaru ${ }^{2,3}$ \\ ${ }^{1}$ Study Program of Marine Science, Faculty of Fisheries and Marine Science, Universitas Padjadjaran, \\ Jatinangor, Sumedang, West Java 45363 Indonesia \\ 2 Department of Marine Science, Faculty of Fisheries and Marine Science, Universitas Padjadjaran, Jatinangor, \\ Sumedang, West Java 45363 Indonesia \\ ${ }^{3}$ Laboratory of Microbiology and Molecular Biotechnology (MICROMOL), Faculty of Fisheries and Marine \\ Science, Universitas Padjadjaran, Jatinangor, Sumedang, West Java 45363 Indonesia
}

* Corresponding Author email: reaverahmadi@gmail.com

Article History

Received: 15 July 2019

Revised: 06 August 2019

Accepted: 19 August 2019

Published: 31 August 2019

Student(s)

- $\quad$ Arif Rahmadi

Academic Year: 2018-19

Course Level: Bachelor

Course Name: Marine Bachelor

Course year: 4th Semester

Mentor(s)

- Yeni Mulyani

- Muhammad Wahyudin Lewaru

\begin{abstract}
A BST RACT
Chaetoceros muelleri is a microalgae class of Bacillariophyta (diatom) which is generally only used as feeds for fishes and shellfish larvae. Nevertheless, the biochemical content of this species is quite high and has the potential to be developed. This research aims to explain the effect of different salinity on the growth and lipid content of Chaetoceros muelleri cultured in a continuous photobioreactor. This research was carried out in August 2018 February 2019. The research was conducted at the Laboratory of Marine Microbiology and the Laboratory of Bioprocess and Bioprospection of Natural Materials, Faculty of Fisheries and Marine Sciences, Padjadjaran University. The samples of Chaetoceros muelleri isolates were obtained from the Jepara Brackish Water Aquaculture Center. The methods used for the study was a 'Completely Randomized Design' (CRD) with four treatments. The salinity used is $15,25,35$ and 45 ppt. The main parameters observed were growth and lipid content, while the supporting parameters were temperature, and $\mathrm{pH}$. The results of this study showed that the highest lipid content was a salinity treatment of 35 ppt with a value of $25.37 \%$ of total dry weight obtained at the end of the culture. Based on growth, the highest density occurred in 25 ppt salinity with a maximum density of $3.80 \pm 0.49 \times 106$ cells. ml-1 and maximum growth rate of 0.36 \pm 0.008 div. day- 1
\end{abstract}

Keywords: Chaetoceros muelleri, Lipid, Photobioreactor 


\section{Introduction}

Microalgae are photosynthetic microorganisms that live in fresh or salty waters. Its presence in nature serves as the first source of nutrition in the food chain. Compared to other photosynthetic organisms, microalgae have a higher lipid content. The production of lipids produced by microalgae also $10-20$ times greater per unit area compared to agricultural products [1].

Marine microalgae species, especially diatoms, are very promising in producing high lipids [2]. One of them is Chaetoceros muelleri. This species belongs to the genus Chaetoceros which is the largest type of phytoplankton diatom spread throughout the ocean [3]. This genus is cosmopolitan and has a fairly high salinity tolerance range of 15-45 ppt. Nowadays, C. muelleri is generally only used as feed for fish and shellfish larvae [4]. Nevertheless, the biochemical content of this species is quite high and has the potential to be developed.

The biochemical compounds contained in microalgae are largely determined by their environmental conditions [5]. Poor environmental conditions will trigger microalgae cells to adapt so that they will change the rate of biosynthesis and biochemistry. Some environmental factors that influence it include temperature, salinity, nutrients, light intensity and degree of safety [5].

Among the factors above, the use of salinity to increase lipid content has its advantages, namely, it is easy to apply on a large scale and low cost. High salt levels cause a series of bioenergy and biochemical changes in photosynthetic organisms. Among them, the most common thing is an increase in lipid biopolymers and changes in the permeability of plasma membranes [5].

Microalgae cultures on a laboratory or industrial scale generally use a bioreactor [6]. The type of reactor that is often used is Photobioreactor. There are two types of a photobioreactor, batch and continuous. The use of batch reactors in microalgae cultures can only maintain a culture for a few days due to nutrient limitations. Meanwhile, the continuous reactor can maintain a longer stationary phase because it can supply nutrients continuously. This can make the accumulation of lipids in microalgae cells can occur optimally. Thus, increasing lipid production from microalgae become more effective

\section{Materials and Method}

\subsection{Continuous culture of Chaetoceros muelleri}

Continuous culture of C. muelleri was carried out in a photobioreactor using 2 liters of C.muelleri culture which had been mixed with NPSi nutrient. The initial culture density in each salinity treatment $(15,25,35$ and $45 \mathrm{ppt}$ ) was $1 \times 10^{6}$ cells. $\mathrm{ml}^{-1}$. The culture was included in each reactor box which had been given $6 \mathrm{~L}$ minute ${ }^{-1}$ aeration. Lighting is set at 3000 lux and nutrient flow is set at $1 \mathrm{ml}^{\text {. day }}{ }^{-1}$. Observation of water quality parameters and growth is carried out every day for 30 days.

\subsection{Continuous culture of Chaetoceros muelleri}

The observed growth parameters were density, growth rate, and optical density. The density measurements were carried out using a Hemocytometer by taking $100 \mu \mathrm{L}$ of culture using a micropipette. Cell counts are calculated using the following formula:

$$
K=\frac{\text { Average cell in one chamber }}{\text { Chamber volume }} \times f
$$

Where $\mathrm{K}$ is the value of density and $\mathrm{F}$ is the dilution factor. The growth rate is calculated using the following equation:

$$
\text { Growth rate }(\mu)(\text { day })^{-1}=\frac{\ln \left(F_{1} / F_{0}\right)}{t_{1}-t_{0}}
$$

Where $\mathrm{F} 1$ is the amount of biomass at the time (t1) and F0 is biomass at the time of initial observation $\left(\mathrm{t}_{0}\right)$. While the optical density was measured using a spectrophotometer at a wavelength of $750 \mathrm{~nm}$. 


\subsection{Harvesting of Biomass}

Harvesting of biomass is carried out in three phases namely exponential phase, stationary initial phase and end of culture. Harvesting of the culture is done by separating $180 \mathrm{ml}$ of culture liquid with biomass. The separation process uses centrifugation at a speed of $2000 \mathrm{rpm}$ for 10 minutes. Then proceed with a drying of biomass.

\subsection{Lipid extraction}

Lipid extraction from microalgae was carried out with the modified Blight-Dyer method. The extraction stage begins by weighing $100 \mathrm{mg}$ of biomass powder and mixing it into $6 \mathrm{ml}$ of $1: 1$ chloroform-methanol solution. Then mix the mixture using vortex for 30 seconds. Re-added $2 \mathrm{ml}$ of $1: 1$ chloroform-methanol solution and $2 \mathrm{ml}$ of distilled water. The mixture was centrifuged for 10 minutes at a speed of $2000 \mathrm{rpm}$. Centrifugation results will produce two layers, the top layer, and the bottom layer. The top layer then discarded and the bottom layer is transferred to the tube. The remaining pellets are extracted again using 4 $\mathrm{ml}$ of 1: 1 chloroform-methanol ratio and filtered using filter paper. The results of pellet extraction were put together in a previous tube and then evaporated at $61^{\circ} \mathrm{C}$. The percentage of the lipid content was determined by the following formula:

$$
\% \text { Lipid }=\frac{\text { Total Lipid Weight }}{\text { Initial weight of biomass }} \times 100 \%
$$

\section{Result and Discussion}

\subsection{Growth Chaetoceros muelleri}

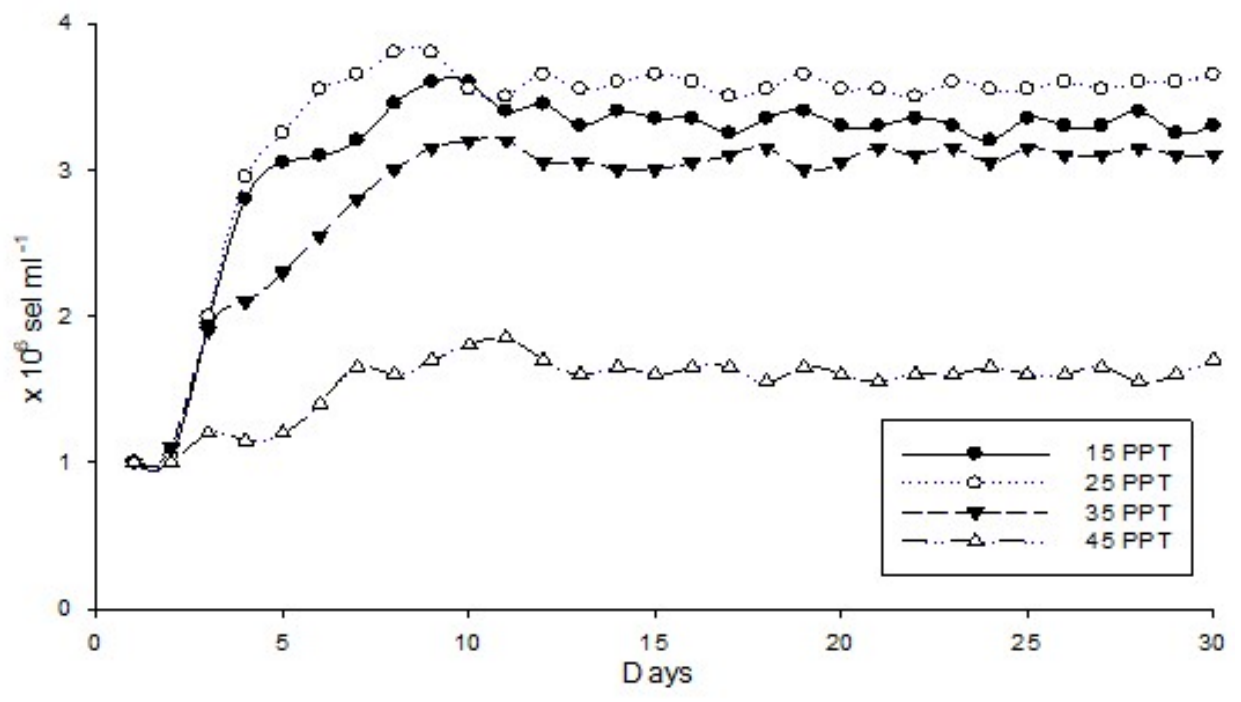

Figure 1: C.muelleri's growth curve during continuous culture

Based on the figure 1, it is known that the duration of the lag phase in all four treatments only occurs one day. This shows that isolates adapt faster. During continuous culture there is no phase of death, which is a special feature of continuous culture. The results of continuous culture (figure 1) show the highest density is in the salinity of $25 \mathrm{ppt}$ with a maximum density reaching $3.8 \times 10^{6}$ cells. $\mathrm{ml}^{-1}$ and the lowest density at salinity 45 ppt with a maximum density of only $1.85 \times 10^{6}$ cells. $\mathrm{ml}^{-1}$. This is similar with the research conducted by Barros et al. which showed that the optimal growth of C.muelleri in his research occurs in salinity 25 ppt [2]. 
The density curve obtained is regressed with the optical density measurement curve as validation. The regression results show that each of each treatment shows a value of $\mathrm{R}>0.78$ which means there is a strong relationship between density and OD.

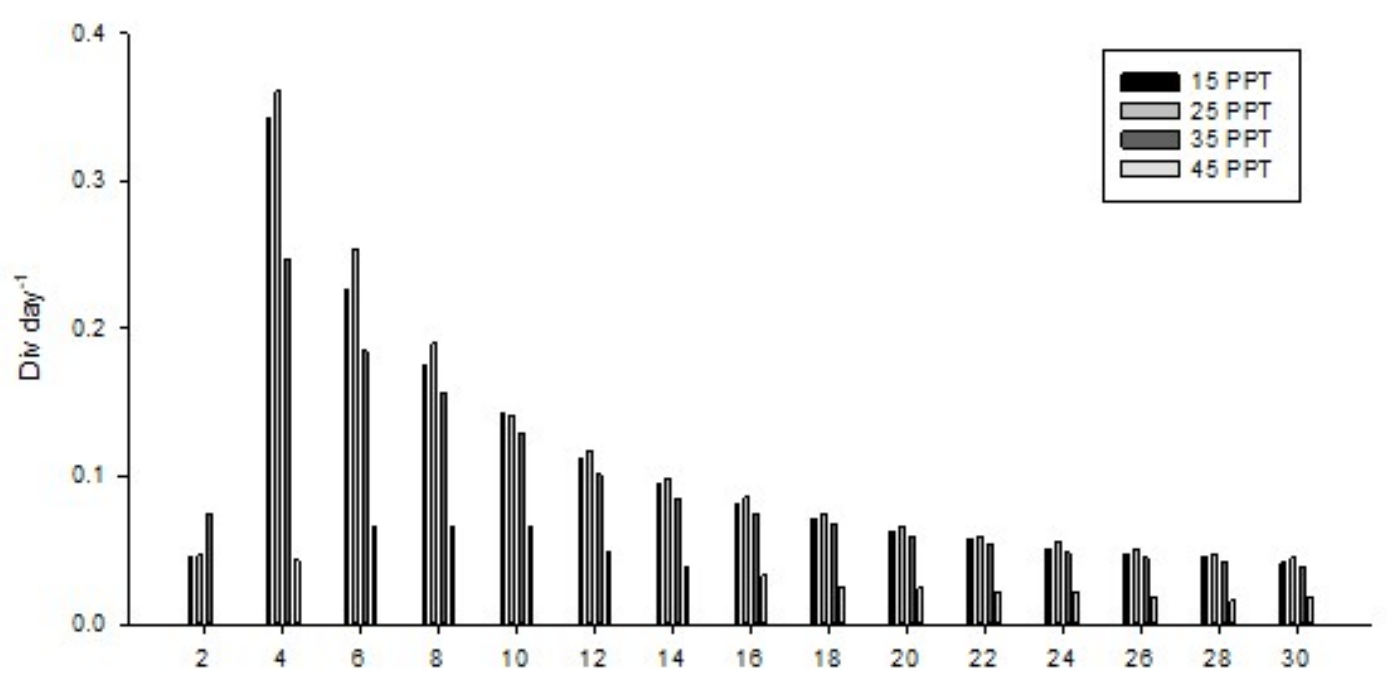

Figure 2: C.muelleri's growth rate during continuous culture

The maximum growth rate also shows the same thing, where the highest value is found in salinity treatment 25 ppt at $0.36 \pm 0.008$ div.days $^{-1}$ and the lowest at 45 ppt treatment at $0.09 \pm 0.073$ div.days $^{-1}$. Based on the figure 2, the maximum growth rate of treatment 15,25 and $35 \mathrm{ppt}$ was on the 4th day while the $45 \mathrm{ppt}$ treatment was achieved on the 8th day. The ANOVA test results for each salinity treatment on density and growth rate show that the value of $\mathrm{p}<0.05$, which means there is a real effect of salinity on density and growth rate

Salinity is one of the limiting factors in the growth of microalgae cells. Salinity can influence osmoregulation activity from cells [7]. When microalgae are at too high a salinity condition, the presence of nutrients for cell growth cannot be absorbed optimally because microalgae carry out the osmose process to maintain the pressure of their cell turgor and tend to store their energy [8]. This process will make cell division slower. This was also shown by Ishika et al. on some spesies diatom which showed that at high salinity concentrations there was a decrease in dry weight of biomass [8].

The reduction in growth in high salinity was caused by a decrease in the rate of photosynthesis in several species of marine microalgae [9]-[10]. This decrease in the rate of photosynthesis is closely related to the activity of PSII (Photosystem II). According to Pancha et al as long as cells adapt to high salinity PSII activity will decrease which can be caused due to damage to the PSII acceptor side and at the PSII reaction center [11].

\subsection{Lipid Content Chaetoceros muelleri}

Calculation of lipid content was also carried out in the three phases of C.muelleri's growth, namely the exponential phase (5th day), the stationary initial phase (10th day) and the stationary end phase (30th day). The results of the calculation of each phase were then statistically analyzed using ANOVA followed by a follow-up test at a significant level of $\mathrm{p}=0.05$. Statistical results of lipid content showed that the value of $\mathrm{p}<0.05$, which means there was a real effect of salinity on the lipid content in each treatment of each phase. The research results showed that there was an increase in lipid content in each treatment along with the length of the growth phase (figure 3). In the exponential phase, it was seen that the highest lipid content was found in the treatment of 15 ppt of $13.43 \pm 0.81 \%$ and the smallest content was found in treatments 35 and 45 ppt where both had almost the same lipid content, $10.67 \pm 1.21 \%$ and $10.47 \pm 1.10 \%$. In this phase, the lipid content is lower than in the other phases. During the exponential phase, microalgae tend 
to use nutrients for the process of division and protein synthesis [12]. Proteins during this phase are needed to form cell structures.

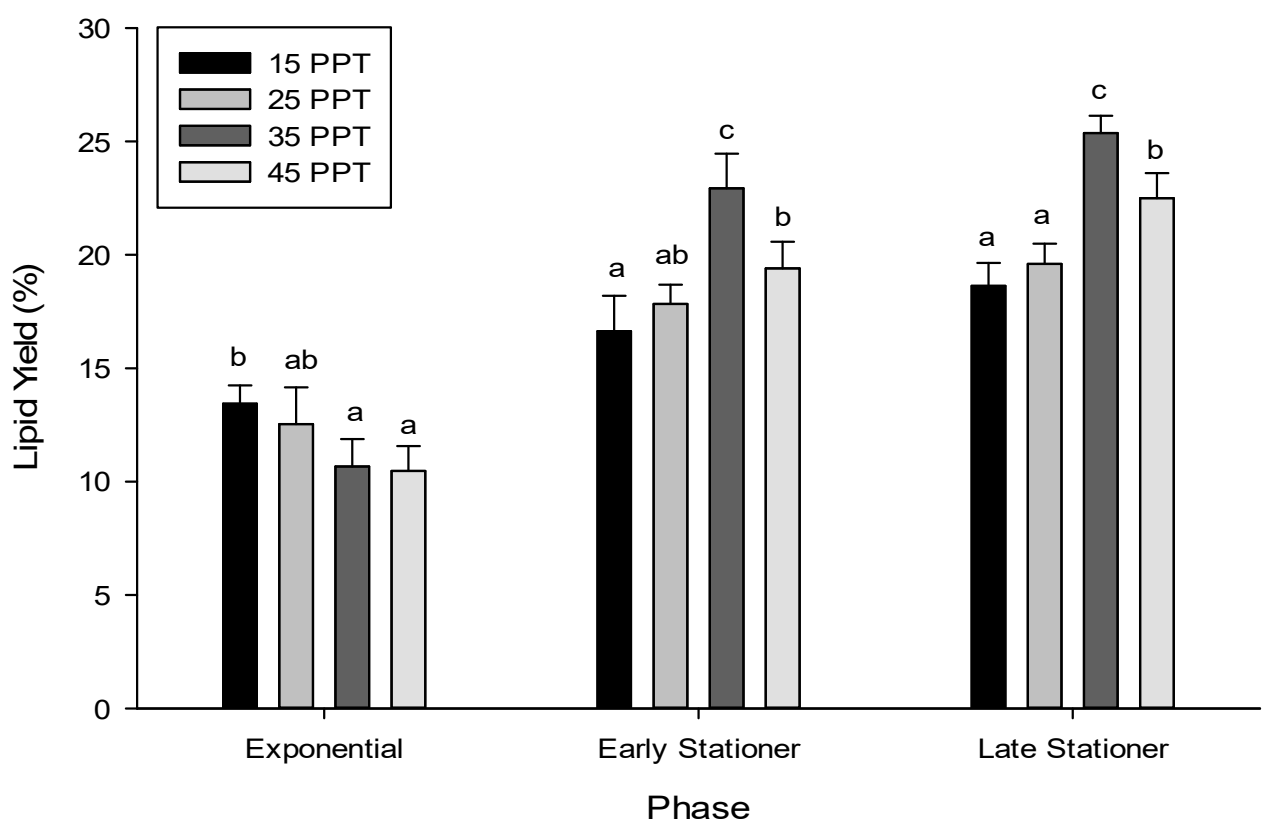

Figure 3: Lipid Content Chaetoceros muelleri

Based on figure 3, the initial stationary phase of four treatments shown an increase in lipid content of \pm 3 $-12 \%$. In this phase, the highest lipid content was found in the treatment of 35 ppt at $22.93 \pm 1.53 \%$ while the lowest at treatment $15 \mathrm{ppt}$ at $16.63 \pm 1.56 \%$. This phase is the phase where the value of cell density is at its peak. Ishika et. al explained that productivity biochemical compounds such as protein and lipids from several species microalga will increase linked increasing cell density until it reaches optimal density [8].

In the final stationary phase (figure 3), the four treatments showed a slight increase in lipid content from the previous phase. Increased lipid content ranges between $\pm 2-3 \%$. The highest lipid content in this phase is still in the salinity treatment of $35 \mathrm{ppt}$ of $25.37 \pm 0.76 \%$ and the lowest is in the treatment of 15 ppt of $18.63 \pm 1.01 \%$. The lipid content in this phase is the highest compared to other phases. According to Barros et.al, the lipid content will increase dramatically in the stationary phase along with decreasing levels of nitrogen and silicates [2]. However, in continuous cultures, nutrient flow is always constant every day so that increased lipids during this phase are thought to be due to the cell's response to salinity. Salinity is one of the environmental factors that affect the growth of microalgae. Poor environmental conditions (outside of optimal conditions) will trigger microalgae cells to adapt so that they will change the rate of biosynthesis and biochemistry [13].

One of the compounds that can be affected is lipids. When cells adapt to salinity conditions, the cell will carry out an osmosis process. During this process, most microalgae will accumulate polyol compounds [13]. One of the polyol compounds commonly found in microalgae is glycerol. Glycerol is a compound needed to form neutral lipid such as triglycerides (TAG). Triglycerides are generally accumulated by microalgae as a backup energy source when the environment is outside optimal conditions [11]. Increased neutral lipid or TAG content along with increased salinity also occurs in several species such as Tetraselmis suecica [11] and Scenedesmus sp. [14]. 


\subsection{Water quality parameter}

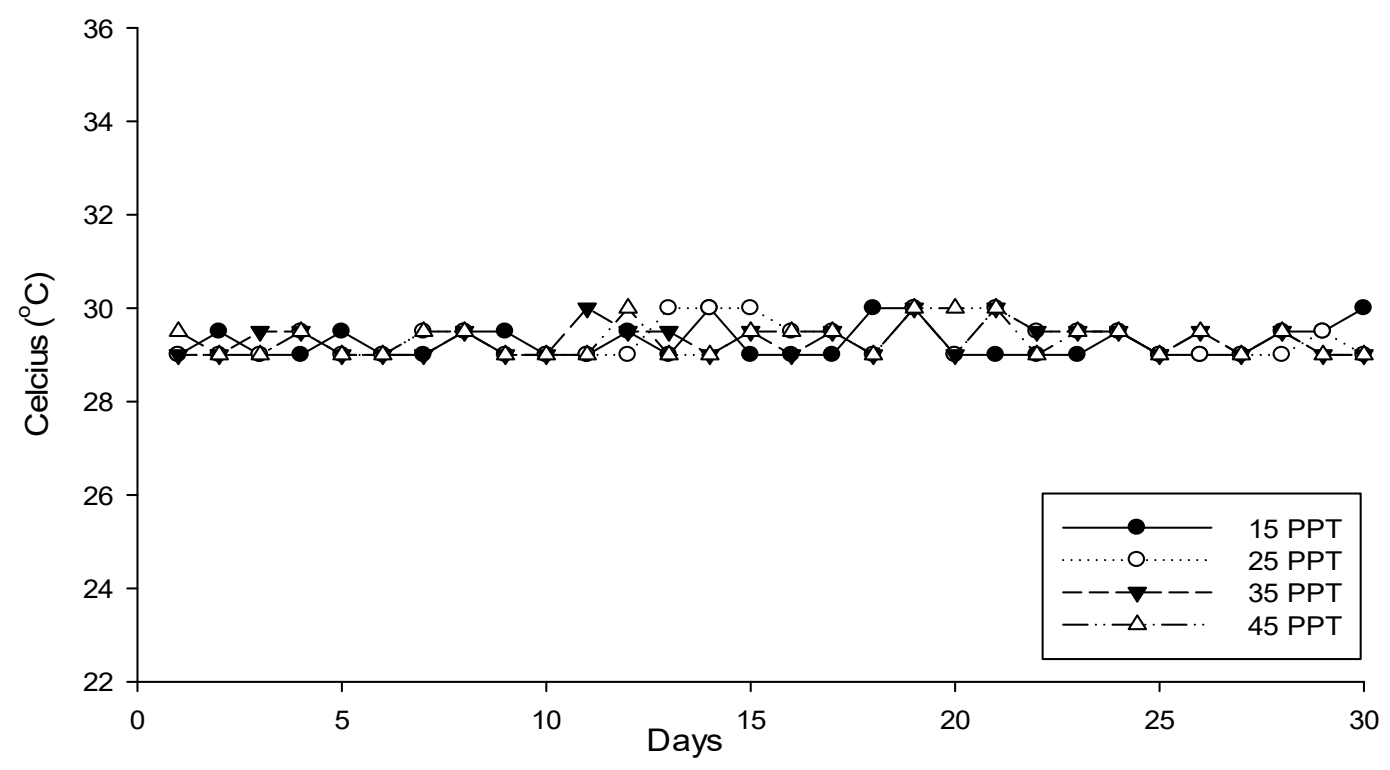

Figure 4: Daily temperature during culture

Based on the results of observations during culture (Figure 4), the daily temperature ranges from $29-30{ }^{\circ} \mathrm{C}$. There is no significant temperature change as long as the culture takes. According to Chaisutyakorn et.al, this species can live at a temperature of $25-40^{\circ} \mathrm{C}$ and its optimal growth is at $30^{\circ} \mathrm{C}$ [1]. The temperature during continuous culture shows that the range is still at the temperature of tolerance of growth of C. muelleri

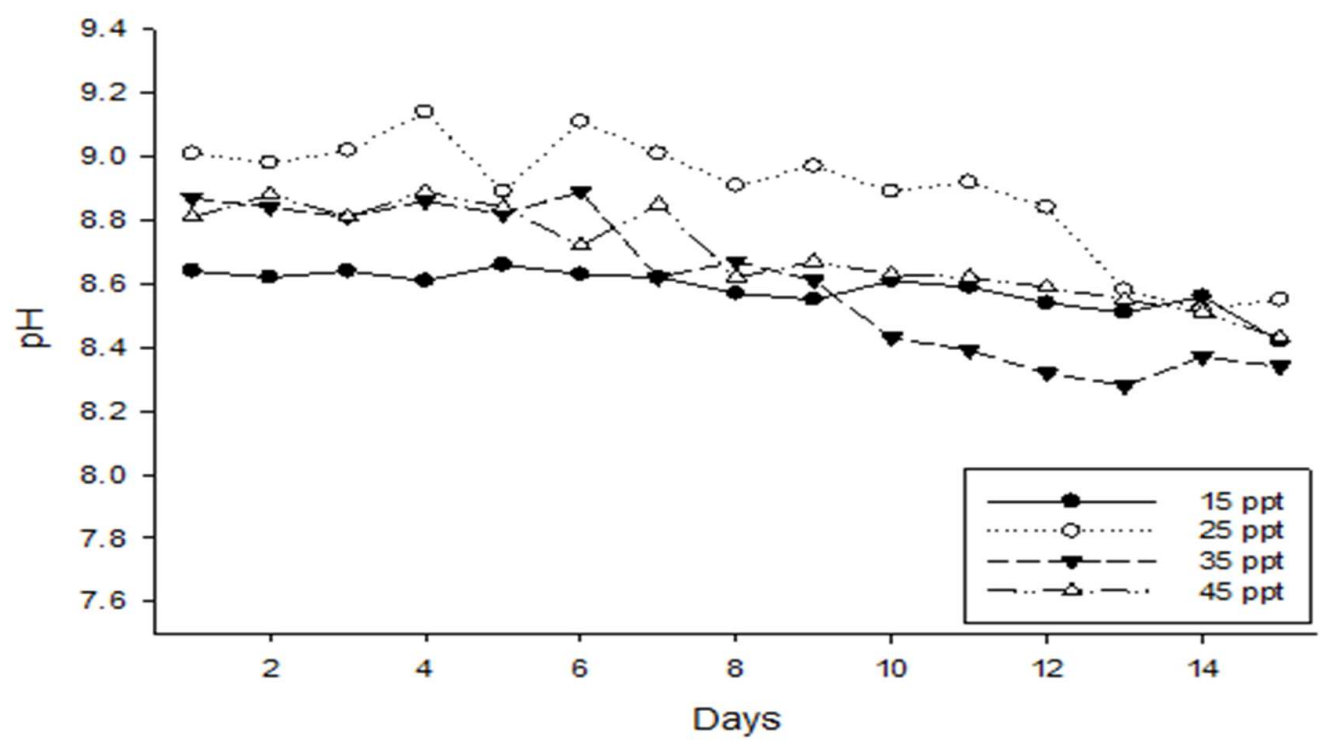

Figure 5: Daily $p H$ during culture

While the results of observations on $\mathrm{pH}$ indicate that the $\mathrm{pH}$ range is in the range 8-9 (figure 5). This value is still in $\mathrm{pH}$ tolerance in C. muelleri. As explained by Jannah et.al, that the $\mathrm{pH}$ range for genus Chaetoceros is 7-9 [15]. Base on figure 5, showed there is a decrease in $\mathrm{pH}$ value but still within the tolerance limit. This can be caused by a decrease in photosynthetic activity. The decrease in photosynthetic activity causes $\mathrm{CO}_{2}$ in the growth medium not to be utilized optimally so that the $\mathrm{pH}$ decreases slightly at the end of the culture. This reduction in photosynthetic activity is thought to be a cell response to salinity conditions. 
Rahmadi et al., Adv. J. Grad. Res.; Vol. 7, Issue 1, pp: 3-10, January 2020

\section{Conclusion}

Salinity has been known to influence the growth and content of biochemical compounds in microalgae species. This study shows the same thing, where each salinity treatment has a different effect, on growth and lipid content in each phase. The highest cell density was obtained at a treatment of 25 ppt with cell density reaching $3.80 \pm 0.49 \times 106$ cells. $\mathrm{ml}^{-1}$ and a maximum growth rate of $0.36 \pm 0.008$ div. day- ${ }^{-1}$. While the lowest cell density was obtained at $45 \mathrm{ppt}$ treatment with a cells density of $1.85 \times 10^{6}$ cells. $\mathrm{ml}^{-1}$ and a growth rate of $0.09 \pm 0.073 \mathrm{div}$. day ${ }^{-1}$. The highest lipid content was obtained in the final stationary phase, at $35 \mathrm{ppt}$ treatment with lipid percentage reaching $25.37 \%$ of the total dry weight. During culture, the lipid accumulation does not occur in the exponential phase only, even when the culture reaches the stationary phase lipid accumulation still occurs. Therefore, increasing lipids using salinity in continuous photobioreactors can be applied to make lipid production effective and maintain microalgae culture longer.

\section{Declarations}

\subsection{Study Limitation}

This research did not classify the fatty acids from the total lipids obtained. This is due to the unavailability of GC-MS devices in The Marine Microbiology laboratory, Padjadjaran University.

\subsection{Acknowledgments}

The authors are grateful to Assoc. Mr. Moh. Untung Kurnia. A. M.Si for his assistance, advising this research and the manuscript.

\subsection{Funding Source}

None

\subsection{Competing Interests}

The authors declared that no conflict of interest exist in the publication of this work.

\section{How to Cite this Article:}

A. Rahmadi, Y. Mulyani, and M. Lewaru, "Effect of Salinity Difference on Lipid Content from Chaetoceros muelleri on Continuous Reactors", Adv. J. Grad. Res., vol. 7, no. 1, pp. 3-10, Aug. 2019. doi:10.21467/ajgr.7.1.3-10

\section{References}

[1] Chaisutyakorn, P., Praiboon, J. \& Kaewsuralikhit, C., "The effect of temperature on growth and lipid and fatty acid composition on marine microalgae used for biodiesel production". J Appl Phycol, pp.1-9. 2017.

[2] Barros, M.U.G. et al., "Lipid content of marine microalgae Chaetoceros muelleri Lemmermann (Bacillariophyceae) grown at different salinities". Biotemas, vol. 27, no. 2, pp.1-8. 2014.

[3] Smodlaka Tanković, Mirta et al. "Insights into the life strategy of the common marine diatom Chaetoceros peruvianus Brightwell." PloS one. vol. 13, no.9e0203634. 12 Sep. 2018.

[4] Jamali, H., Ahmadifard, N. \& Abdollahi, D. "Evaluation of growth, survival and body composition of larval white shrimp (Litopenaeus vannamei) fed the combination of three types of algae". Int Aquat Res. vol.115, no.7. 2015.

[5] Benavente-valdés, J.R. et al. "Strategies to enhance the production of photosynthetic pigments and lipids in chlorophycae species". Biotechnology Report, vol.10, pp.117-125. 2016.

[6] Siqueira, S. F., Francisco, É. C., Queiroz, M. I., Menezes, C. R. de, Zepka, L. Q., \& Jacob-Lopes, E. "Third Generation Biodiesel Production From Microalgae Phormidium autumnale”. Brazilian Journal of Chemical Engineering, vol.33, no.3, pp. 427-433. 2016.

[7] BenMoussa-Dahmen, I., Chtourou, H., Rezgui, F., Sayadi, S., \& Dhouib, A.. "Salinity stress increases lipid, secondary metabolites and enzyme activity in Amphora subtropica and Dunaliella sp. for biodiesel production”. Bioresource Technology, vol. 218, pp.816825. 2016.

[8] Ishika, T., Moheimani, N. R., Bahri, P. A., Laird, D. W., Blair, S., \& Parlevliet, D. . "Halo-adapted microalgae for fucoxanthin production: Effect of incremental increase in salinity". Algal Research, vol. 28, pp.66-73. 2017.

[9] Ji, X., Cheng, J., Gong, D., Zhao, X., Qi, Y., Su, Y., \& Ma, W. "The effect of NaCl stress on photosynthetic efficiency and lipid production in freshwater microalga-Scenedesmus obliquus XJ002". Science of The Total Environment, vol. 633, pp. 593-599. 2018.

[10] Du, Z.-Y., \& Benning, C. Triacylglycerol Accumulation in Photosynthetic Cells in Plants and Algae. Lipids in Plant and Algae Development, 179-205. 2016.

[11] Pancha, I., Chokshi, K., Maurya, R., Trivedi, K., Patidar, S. K., Ghosh, A., \& Mishra, S. "Salinity induced oxidative stress enhanced biofuel production potential of microalgae Scenedesmus sp. CCNM 1077”. Bioresource Technology, vol.189, pp. 341-348. 2015. 
[12] Paes, Caroline R.P.S. et al. "Growth, nutrient uptake and chemical composition of Chlorella sp. and Nannochloropsis oculataunder nitrogen starvation". J.Aquatic. vol. 42, no. 2, pp.275-292. 2016.

[13] Paliwal, C., Mitra, M., Bhayani, K., Bharadwaj, S. V. V., Ghosh, T., Dubey, S., \& Mishra, S. “Abiotic stresses as tools for metabolites in microalgae". Bioresource Technology, vol. 244, pp.1216-1226. 2017.

[14] Houslow, Emily. et al. 2016. "The Search for a lipid trigger: The Effect of salt stress on the lipid profile of model microalgal species chlamydomonas reinhardtii for biodiesel production". Current Biotechnology. vol. 5, pp.305-313. 2016.

[15] Jannah, M., Ulkhaq, M. F., Azhar, M. H., Suciyono, \& Soemarjati. "Growth Performance of Laboratory-Scale Chaetoceros calcitrans in Different Containers”. IOP Conference Series: Earth and Environmental Science, vol. 236, No. 012031, 2019.

\section{Publish your books with AIJR publisher-}

$\checkmark \quad$ Publish with ISBN and DOI.

$\checkmark$ Publish Thesis/Dissertation as Monograph.

$\checkmark$ Publish Book Monograph.

$\checkmark$ Publish Edited Volume/ Book.

$\checkmark$ Publish Conference Proceedings

$\checkmark \quad$ Retain full copyright of your books.

Submit your manuscript at books.aijr.org
Publish your research article in AIJR journals-

$\checkmark \quad$ Online Submission and Tracking

$\checkmark$ Peer-Reviewed

$\checkmark$ Rapid decision

$\checkmark$ Immediate Publication after acceptance

$\checkmark \quad$ Articles freely available online

$\checkmark \quad$ Retain full copyright of your article.

Submit your article at journals.aijr.in 